\title{
Water level influences on body condition of Geophagus brasiliensis (Perciformes: Cichlidae) in a Brazilian oligotrophic reservoir
}

\author{
Alejandra Filippo Gonzalez Neves dos Santos, \\ Luciano Neves dos Santos and Francisco Gerson Araújo
}

\begin{abstract}
Effects of water level fluctuations on body condition of Geophagus brasiliensis were studied in a $30 \mathrm{~km}^{2}$ Brazilian oligotrophic reservoir. Physiological condition (K) and gonadosomatic index (GSI) were compared according to water level (low and high). Females' best conditions were associated to higher resources availability during high water, since gonad development did not change between low and high water. Males' condition did not change between water levels, while the highest gonad development occurred in low water. Females presented higher reproductive investment than males, which allocated most of energy for somatic development. This strategy could be a mechanism to undergo the stress caused by oligotrophic characteristics of the reservoir enhanced during low water level.
\end{abstract}

Efeitos do nível da água na condição de Geophagus brasiliensis foram analisados em um reservatório oligotrófico. A condição fisiológica (K) e o índice gonadossomático (IGS) foram comparados entre os níveis da água (baixo e alto). Melhores condições de fêmeas foram associadas a maiores disponibilidades de recursos no nível alto, já que o desenvolvimento gonadal não variou. Não foram registradas diferenças na condição de machos, contudo maiores valores de IGS ocorreram no nível baixo. Fêmeas apresentaram elevado investimento reprodutivo, enquanto machos investiram mais no desenvolvimento somático. Tal estratégia pode ser um mecanismo para suportar o estresse causado pelas características oligotróficas do reservatório, intensificadas durante o período de níveis baixos da água.

Key words: Environmental variables, condition factor, gonadosomatic index, mass-length relationship, impoundment.

\section{Introduction}

Water level oscillations in man-made lakes affect directly habitat complexity and other aspects of ecological niche with strong influences on fish composition and populations structure (Beam, 1983). High water levels have been associated to high food supply and shelter availability, favoring early life stages development, while low water levels are associated with eggs and larvae exposure trigging intense mortalities (Savino \& Stein, 1982; Maceina \& Stimpert, 1998; Sammons et al., 1999). High water levels can also alter reservoirs trophic state since expansion of littoral zone and flooding of marginal vegetation increase input of organic matter and chemical nutrients, enhancing primary productivity (Thornton et al., 1990; Esteves, 1998). Influences of water level fluctuations on fish condition are rather controversial. Some papers state that high water level contribute to improve fish condition (Jepsen et al., 1997), while others found no significant influences (McKinney et al., 1999; Spranza \& Stanley, 2000). Overall, water level likely influences fish condition, since it changes several water quality and physical constraints, mainly in oligotrophic systems (Williams et al., 1998)

Condition factor reflects the physiological state of a fish, which suffer influences from both intrinsic (gonad development, organic reserves) and extrinsic (food availability, environmental stress) variables (Nikolsky, 1969). Several authors 
(Vazzoler \& Vazzoler, 1965; Das \& Pathani, 1978; Htun-Han, 1978; Barbieri \& Barbieri, 1984; Spranza \& Stanley, 2000; VilaGispert \& Moreno-Amich, 2001) also reported changes in condition related to reproductive period and food availability. Gonadosomatic index (GSI) has been applied to assess the energy investment on reproduction and/or to evaluate gonads influences on body condition (Spranza \& Stanley, 2000; Mazzoni \& Rios, 2002).

The present study aims to determine water levels influences on body condition of the pearl eartheater Geophagus brasiliensis (Quoy \& Gaimard, 1824), an abundant and widely spread fish species throughout freshwater environments in Brazil (Lowe-McConnell, 1991; Angelini \& Petrere-Jr, 1996). G. brasiliensis is an omnivorous-opportunist species that has successfully adapted to Lajes Reservoir, in Rio de Janeiro State, Southeast Brazil, which experienced remarkable water level fluctuations. We tested the hypothesis that high water level could increase fish body condition by allowing favorable environmental constraints linked to food and shelter availability.

\section{Material and Methods}

\section{Study area}

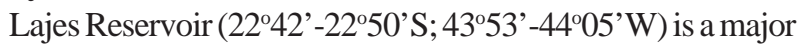
impoundment in Rio de Janeiro State, located in the upper slopes of the Serra do Mar (Southeast Brazilian Coast). The reservoir, situated at $415 \mathrm{~m}$ above mean sea level, was filled for hydroelectric purposes, between 1905 and 1908, damming streams of Serra do Mar and diverting small rivers (Araújo \& Santos, 2001). The altitude influences the tropical humid climate that could be characterized by two distinct seasons: a wet, from late spring to early autumn; and a dry, from late autumn to early spring (Barbieri \& Kronemberg, 1994).

Overall, the reservoir is oligotrophic and is surrounded by well-preserved stretches of Atlantic Forest. This reservoir presents low concentrations of nitrogen $\left(<10 \mu \mathrm{gL}^{-1}\right)$, phosphate $\left(<120 \mu \mathrm{gL}^{-1}\right)$ and chlorophyll $\alpha\left(<2.5 \mu \mathrm{gL}^{-1}\right)$ (Santos, 2002). Recent studies have reported trends of nutrient enrichment in the reservoir, mainly phosphorus, which could be related to the increased anthropogenic activities (diffuse pollution) associated to high water residence time (286 days) (Table 1 ).

The reservoir experiences remarkable water level fluctuations, dictated by rainfall and by dam operation for hydroelectric purposes, resulting in two physical and chemical distinct periods (Table 1): 1 - low water levels (Spring-Summer) characterized by higher temperatures and rainfall, lower nutrient and chlorophyll $\alpha$ concentrations; and 2 - high water levels (Autumn-Winter) with lower temperatures and rainfall, higher nutrient and chlorophyll $\alpha$ concentrations, and higher habitat complexity, food and shelter availability. Although overall water level fluctuations averaged nearly $3.0 \mathrm{~m}$, extreme differences between high and low water levels can reach up to 12.0 m (Duarte \& Araújo, 2001).

\section{Fish sampling and data analysis}

Fishes were collected monthly in 1994, 1996 and 1999/ 2000, by seine, cast nets and gill nets. Individuals were identified, weighted (grams) and measured to total length (millimeters). Voucher specimens were preserved in 10\% formalin and later deposited in the Ichthyological Collection of Laboratório de Ecologia de Peixes, Universidade Federal Rural do Rio de Janeiro, Brazil.

Length-weight relationship parameters were determined through ordinary linear regression from $\ln \left(\log _{\mathrm{e}}\right)$ transformed TW and TL. Natural logarithm was used which resulted in the following linear regression: $\ln \mathrm{TW}=\ln \mathrm{A}+\mathrm{B} \ln \mathrm{TL}$.

Slope and intercept were determined and used to estimate the curve parameters as follows: $\mathrm{a}=\mathrm{e}^{\mathrm{A}}$, and $\mathrm{b}=\mathrm{B}$ (Santos, 1978). Slope corresponds to allometric coefficient that determines the form of growth of a given population; a tStudent test $(\mathrm{p}<0.05)$ was applied to compare differences

Table 1. Major physical and chemical characteristics (means \pm standard error) of the Lajes Reservoir, with differences between low and high water levels periods.

\begin{tabular}{|c|c|c|c|c|c|c|c|c|c|c|}
\hline \multirow{3}{*}{$\begin{array}{l}\text { Environmental } \\
\text { Variables } \\
\text { Water level }(\mathrm{m})\end{array}$} & \multirow{2}{*}{\multicolumn{3}{|c|}{ Overall }} & \multicolumn{6}{|c|}{ Water level period } & \multirow[t]{2}{*}{ References } \\
\hline & & & & \multicolumn{3}{|c|}{ Low } & \multicolumn{3}{|c|}{ High } & \\
\hline & 410.8 & \pm & 0.08 & 409.4 & \pm & 0.09 & 412.4 & \pm & 0.07 & \multirow{8}{*}{$\begin{array}{l}\text { Araújo \& Santos (2001) } \\
\text { Duarte (2001) } \\
\text { Duarte \& Araújo (2001) } \\
\text { Santos (2002) } \\
\text { Gonzalez (2003) }\end{array}$} \\
\hline Rainfall (mm.month ${ }^{-1}$ ) & 97.0 & \pm & 3.67 & 144.9 & \pm & 5.32 & 45.6 & \pm & 2.61 & \\
\hline Temperature $\left({ }^{\circ} \mathrm{C}\right)$ & 24.9 & \pm & 0.14 & 26.7 & \pm & 0.18 & 22.9 & \pm & 0.15 & \\
\hline Oxygen $\left(\mathrm{mg} \cdot \mathrm{L}^{-1}\right)$ & 6.7 & \pm & 0.13 & 6.7 & \pm & 0.28 & 6.6 & \pm & 0.13 & \\
\hline Transparency (m) & 2.6 & \pm & 0.05 & 2.3 & \pm & 0.06 & 2.8 & \pm & 0.06 & \\
\hline Turbidity (NTU) & 6.9 & \pm & 0.47 & 8.8 & \pm & 0.68 & 5.0 & \pm & 0.63 & \\
\hline $\mathrm{pH}$ & 6.8 & \pm & 0.05 & 7.0 & \pm & 0.04 & 6.6 & \pm & 0.08 & \\
\hline Conductivity $\left(\mu \mathrm{S} . \mathrm{cm}^{-1}\right)$ & 22.1 & \pm & 0.15 & 22.9 & \pm & 0.17 & 21.3 & \pm & 0.24 & \\
\hline Nitrogen $\left(\mathrm{mg} \cdot \mathrm{L}^{-1}\right)$ & 2.8 & \pm & 0.10 & 2.6 & \pm & 0.14 & 3.0 & \pm & 0.15 & \multirow{5}{*}{$\begin{array}{l}\text { LIGHT - Water quality } \\
\text { monitoring database (1998-2003) }\end{array}$} \\
\hline Nitrate $\left(\mathrm{mg} \cdot \mathrm{L}^{-1}\right)$ & 0.9 & \pm & 0.06 & 0.8 & \pm & 0.09 & 1.0 & \pm & 0.07 & \\
\hline Phosphorus (mg. $\left.\mathrm{L}^{-1}\right)$ & 0.6 & \pm & 0.03 & 0.2 & \pm & 0.02 & 1.0 & \pm & 0.06 & \\
\hline Sulfate $\left(\mathrm{mg} \cdot \mathrm{L}^{-1}\right)$ & 1.2 & \pm & 0.10 & 1.1 & \pm & 0.16 & 1.3 & \pm & 0.08 & \\
\hline Chlorophyll $\alpha\left(\mathrm{mg} . \mathrm{L}^{-1}\right)$ & 2.0 & \pm & 0.30 & 1.9 & \pm & 0.13 & 2.2 & \pm & 0.67 & \\
\hline Habitat complexity & \multicolumn{3}{|c|}{ Low } & \multicolumn{3}{|c|}{ Very low } & \multicolumn{3}{|c|}{ Medium-High } & Santos (2002) \\
\hline Food and shelter availability & \multicolumn{3}{|c|}{ Low } & \multicolumn{3}{|c|}{ Very low } & \multicolumn{3}{|c|}{ Medium-High } & Personal observation \\
\hline
\end{tabular}


between sexes and to determine if each value differed significantly from 3.0 (isometric condition).

Condition factor $(\mathrm{K})$ was determined by the following equation: $\mathrm{K}=\mathrm{TW} / \mathrm{TL}^{\mathrm{b}}$ (Le Cren 1951). The gonadosomatic index (GSI) was calculated according to the equation: $\mathrm{GSI}=\mathrm{GW} /(\mathrm{TW}-\mathrm{GW}$ ), where: $\mathrm{GW}=$ gonad weight, $\mathrm{TW}=$ total body weight. A t-Student test was used to compare condition and GSI between sexes by fish size at 95\% significance level; one-way ANOVA was used to compare condition and GSI between sex and water level (Zar, 1974).

\section{Results}

Weight-length relationship was determined from a total of 149 individuals, 87 females and 62 males, with size ranging from $128-295 \mathrm{~mm}$ for females and $112-300 \mathrm{~mm}$ for males. Results of the linear regression obtained from this relationship for the whole population is showed in Table 2 .

Allometric coefficient for the whole populations averaged 2.85 , with females presenting 2.85 and males 2.84 (Table 2); the t-Student test did not revealed any significant difference in this parameter between sexes $(\mathrm{t}=0.15 ; \mathrm{p}>0.05)$, but both values differed significantly from $3.0(\mathrm{t}=6.92, \mathrm{p}<0.01$ for males; $\mathrm{t}=$ $5.90, \mathrm{p}<0.01$ for females), indicating negative allometry.

Mean value ( \pm standard error) for $\mathrm{K}$ for the whole population was $4.0 \times 10^{-5}\left( \pm 3.9 \times 10^{-7}\right)$, with females presenting 4.0 $\times 10^{-5}\left( \pm 5.2 \times 10^{-7}\right)$ and males $4.4 \times 10^{-5}\left( \pm 6.6 \times 10^{-7}\right)$. Significant difference $(\mathrm{t}=4.96 ; \mathrm{p}<0.001)$ in $\mathrm{K}$ values was determined for the entire population with higher values for males.

Significant differences in K were found between sex for size class with males showing comparatively higher values than females in size classes $>200 \mathrm{~mm}(\mathrm{p}<0.05)$ (Fig. 1). ANOVA revealed highly significant difference between sexes $(\mathrm{F}=23.86$; $\mathrm{p}<0.001$ ) with higher values for males than females, and significant differences among water levels $(\mathrm{F}=6.14 ; \mathrm{p}=0.014)$ only for females (Fig. 2).

The gonadosomatic index (GSI), as expected, showed significant differences between sexes with females' values higher than males $(t=5.02 ; \mathrm{p}<0.001)$ and these differences were attributed to size classes $>200 \mathrm{~mm}$ (Fig. 3); an exception was found for size classes $275-300 \mathrm{~mm}$, probably due to low number of females. ANOVA revealed highly significant difference between sexes $(\mathrm{F}=23.05 \mathrm{p}<0.001)$ with higher values for males than females, as expected. Significant differences among water levels were found only for males, with higher values during low water (Fig. 4).

Table 2. Regression parameters from logarithm data by $\operatorname{lnTW}$ $=\mathrm{A}+\mathrm{B} \operatorname{lnTL}$ on total weight (dependent) and total length (independent) for males and females of Geophagus brasiliensis in Lajes Reservoir. N - number of individuals; A - intercept; B - slope and R2 - determination coefficient.

\begin{tabular}{lcccc}
\hline Sex & $\mathrm{N}$ & $\mathrm{B}$ & $\mathrm{A}$ & $\mathrm{R}^{2}$ \\
\hline Male & 62 & 2.8366 & -10.033 & 0.97 \\
Female & 87 & 2.8518 & -10.133 & 0.95 \\
\hline All Population & 149 & 2.8541 & -10.138 & 0.96 \\
\hline
\end{tabular}

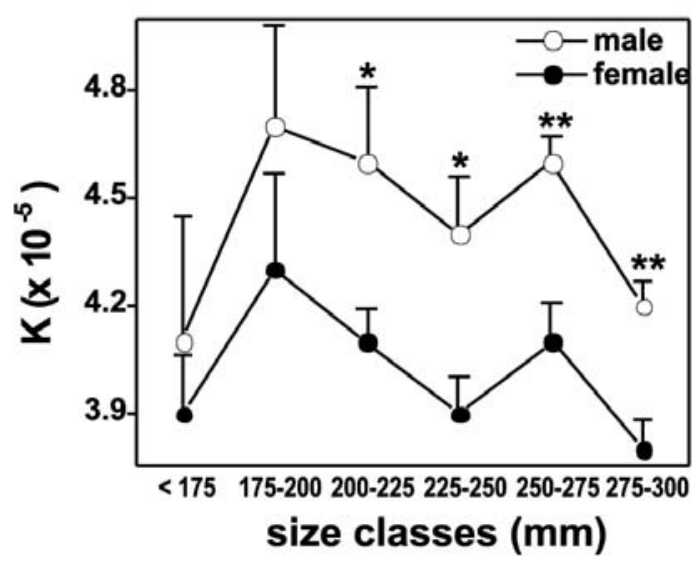

Fig. 1. Means and standard errors (vertical lines) for condition (K) by sex and size classes for Geophagus brasiliensis in the Lajes Reservoir. Between-sex significant differences: $* p<$ $0.05 ; * * \mathrm{p}<0.01$.

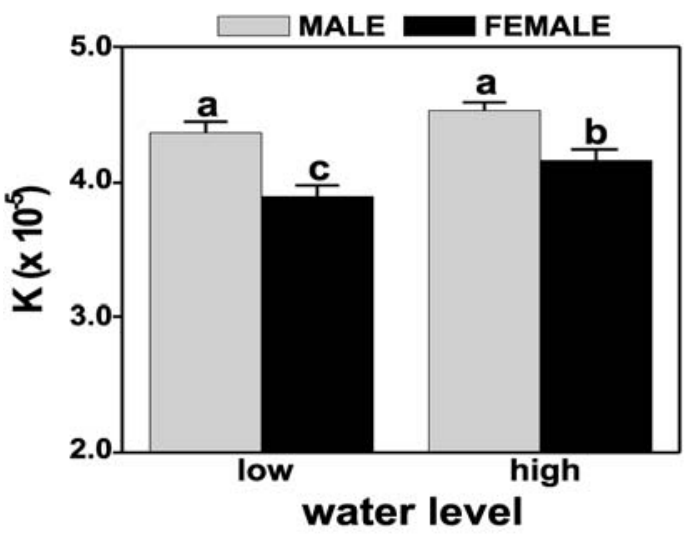

Fig. 2. Means and standard errors (vertical lines) for body condition (K) by sex and water level periods for Geophagus brasiliensis in the Lajes Reservoir. Distinct letters (a, b, c) indicate significant differences at $95 \%$ level of confidence.

\section{Discussion}

The relatively low $\mathrm{K}$ averages values found in this work (males $=0.000044$; females $=0.000040)$ are well below those determined by Barbieri \& Santos (1981), which found 0.000094 for males and 0.000086 for females, and this could represent differences in trophic characteristics between the two reservoirs. Overall, Lajes Reservoir can be classified as oligotrophic, due to low nutrient (mainly nitrogen) and chlorophyll $\alpha$ concentrations (Table 1 ) while Lobo Reservoir is known as a typically mesotrophic environment (Rodríguez $\&$ Matsumura-Tundisi, 2001). The trophic state plus the wide oscillations in water level limit space (shelters) and food availability, being probably the determinant factors for the low K values.

High water level coincides with flooding of margins, 
vegetation decomposition, nutrient and primary productivity enhancement favoring weight gain, by increasing food and shelter availability. On the other hand, low water level reduces food and shelter availability by exposing margins, increasing resources competition and vulnerability to predation (Savino \& Stein, 1982; McKinney et al., 1999). Gut contents of top abundant fish species in Lajes Reservoir indicated that G. brasiliensis is a common prey of Hoplias malabaricus (Bloch, 1794) and Rhamdia parahybae (Steindachner, 1877), and overlap trophic niche with Metynis maculatus (Cope, 1878) and Tracheolypterus striatulus (Steindachner, 1876) (first author personal observations). As consequence, G. brasiliensis probably spend part of its energetic budget avoiding predation and/or competing for resources during low water level.

Overall, males G. brasiliensis showed higher condition than

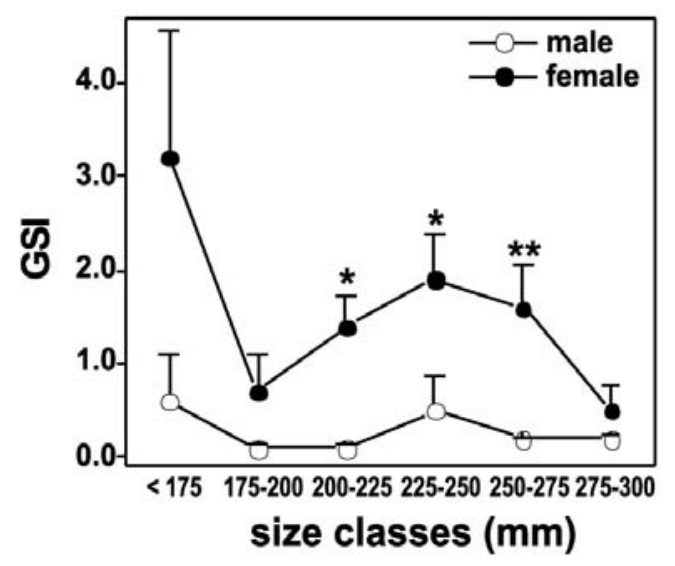

Fig. 3. Means and standard error (vertical lines) for gonadosomatic index (GSI) by sex and size classes for Geophagus brasiliensis in the Lajes Reservoir. Between-sex significant differences: $* \mathrm{p}<0.05 ; * * \mathrm{p}<0.01$.

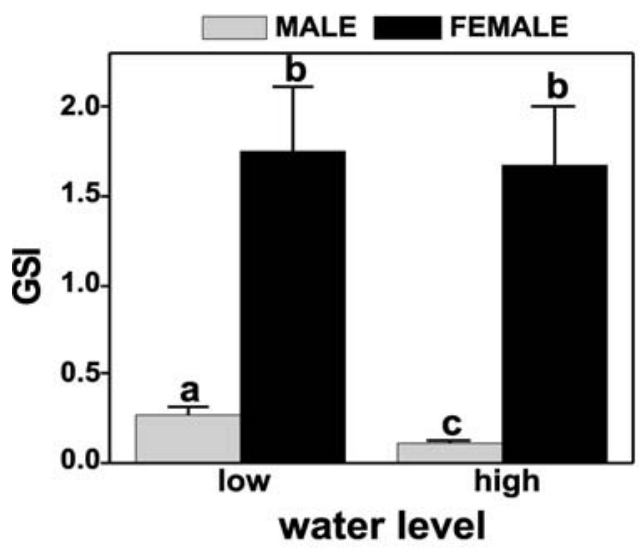

Fig. 4. Means and standard errors (vertical lines) for gonadosomatic index (GSI) by sex and water level periods for Geophagus brasiliensis in the Lajes Reservoir. Distinct letters $(a, b, c)$ indicate significant differences at 95\% level of confidence. females but significant differences among water levels were found only for females, with highest values in high water level. Best environmental conditions during high water could allow higher energetic investment on individual condition for both sexes. Males probably allocate more energetic budget to somatic development, since they present similar condition irrespective the water level and lower GSI in high water. On the other hand females allocate similar energetic investment on reproduction in both water levels, taking more advantages during high water level for body investment. This strategy could be a mechanism to undergo the stress caused by oligotrophic characteristics of the reservoir mainly during low water level.

Variation in K and GSI between males and females according to size classes reinforce the hypothesis of differentiated energetic investment by sex. For individuals larger than $200 \mathrm{~mm}$ TL, the differentiation in investment by sex is confirmed with males showing higher body investment $(\mathrm{K})$, while females showed higher reproduction investment (GSI).

The overall average of the allometric coefficient for $G$. brasiliensis population in the Lajes Reservoir (2.85) differed significantly from 3.0. According to Le Cren (1951) the allometric coefficient depends on genetic background of species, and should be constant in a given population. G. brasiliensis in Lajes Reservoir presented allometric coefficient close with the expecting limit indicated by Le Cren (1951), who reported the range from 2.5 to 4.0 for the majority of fish populations. The reference value of 3.0 indicates that the fish maintain the same form over ontogenetic development, with a balanced proportion between weight and length. Values significantly higher than 3.0 indicate that species became more "rounded" as they grow and lower than 3.0 indicate that became more "stream-lined" with higher size. Therefore, negative allometry found in this study points to a comparatively higher increment in length than weight as size increases.

Negative allometry found in this work is below the 3.05 for Ponte Nova Reservoir (Mota et al., 1983), 2.97 for Lobo Reservoir (Barbieri \& Santos, 1981) and 2.96 for Segredo Reservoir (Benedito-Cecilio \& Agostinho, 1997) populations, which had been reported as isometric growth. Comparisons of allometric coefficient among different systems are rather controversial, since all fish population size should be represented in the analyses. Additionally, oligotrophic characteristics of the Lajes Reservoir could be contributing to negative allometry for $G$. brasiliensis, especially when compared with other populations such as the one from the Lobo Reservoir, which is described as meso/ eutrophic (Rodríguez \& Matsumura-Tundisi, 2001). Williams et al. (1998) found increased allometric coefficient in cichlids (from 2.7 to 3.1 ) in a hiper-oligotrophic reservoir that experienced a rise in resource availability. Increasing in allometric coefficient from 2.9 to 3.1, between pre and postimpoundment phases of Serra da Mesa Reservoir was reported for the congeneric G. surinamensis (Petito, 2002). Negative allometry (2.61) was also found for Cichla monoculus (Schneider, 1828) in Lajes Reservoir (Santos et 
al., 2001). Therefore it is reasonable to suppose that the trophic state of reservoirs could be linked to shifts in allometric coefficient of fish populations.

\section{Acknowledgements}

We specially thank to Sebastião Paulino and Ricardo Bichara, for allowing us to use information on LIGHT water quality monitoring database (1998-2003). We also thank to technicians and undergraduate students at Fish Ecology Laboratory, University Federal Rural of Rio de Janeiro, for helping in field and laboratory work. This work was partially financed by Brazilian Agency for Research Development $\mathrm{CNPq}$ and Brazilian Ministry of Education Coordination for Personal Training - CAPES. LIGHT Services of Electricity S.A., concessionaire of the Lajes Reservoir, supplied infrastructure, essential to the project development and additional financial support.

\section{Literature Cited}

Angelini, R. \& M. Petrere Jr. 1996. The ecosystem of Broa reservoir, São Paulo State, Brazil, as described using ecopath. Naga The Iclarm Quarterly, 19 (2): 36-41.

Araújo, F. G. \& L. N. Santos. 2001. Distribution of fish assemblages in Lajes reservoir, Rio de Janeiro, Brazil. Brazilian Journal of Biology, 61 (4): 563-576.

Barbieri, E. B. \& D. M. Kronemberg. 1994. Climatologia do litoral sul-sudeste do Estado do Rio de Janeiro: um subsídio à análise ambiental. Cadernos de Geociências, 12: 57-74.

Barbieri, G. \& M. C. Barbieri. 1984. Note on nutritional dynamics of Gymnotus carapo from the Lobo reservoir, São Paulo State, Brazil. Journal of Fish Biology, 24: 351-355.

Barbieri, G. \& R. Santos. 1981. Dinâmica da nutrição de Geophagus brasiliensis (Quoy \& Gaimard, 1824), na represa do Lobo, Estado de São Paulo, Brasil. Ciência e Cultura, 32 (1), 87-95.

Beam, J. H. 1983. The effect of annual water level management on population trends of White crappie in elk city reservoir, Kansas. North American Journal of Fisheries Management, 3: 34-40.

Benedito-Cecilio, E. \& A. A. Agostinho. 1997. Estrutura das populações de peixes do reservatório de Segredo. Pp. 113135. In: Agostinho, A. A. \& L. C. Gomes (Eds.). Reservatório de Segredo - Bases ecológicas para o manejo. Maringá, Eduem, 381p.

Das, S. M. \& S. S. Pathani. 1978. Studies on the biology of the Kumaun mahaserr (tor putitora Hamilton): adaptation of the alimentary tract in relation to feeding habits body length and body weight. Indian Journal of Animal Science, 48: 461-465.

Duarte, S. 2001. Estrutura da população e biologia reprodutiva de duas espécies de cascudos (Siluriformes, Loricariidae), na represa de Ribeirão das Lajes. Unpublished Ms.C. Dissertation, Universidade Federal Rural do Rio de Janeiro, Rio de Janeiro. 97p.
Duarte, S. \& F. G. Araújo. 2001. Abundância relativa e distribuição de Loricariichthys spixii (Steindachner) (Siluriformes, Loricariidae) no reservatório de Lajes, Estado do Rio de Janeiro, Brasil. Revista Brasileira de Zoologia, 18 (2): 465-477.

Esteves, F. A. 1998. Fundamentos de limnologia. Rio de Janeiro, Interciência, 602p.

Gonzalez, A. F. 2003. Alimentação e ecologia trófica do tucunaréamarelo Cichla monoculus (Spix, 1829) no reservatório de Lajes. Unpublished Ms.C. Dissertation, Universidade Federal Rural do Rio de Janeiro, Rio de Janeiro. 123p.

Htun-Han, M. 1978. The reproductive biology of the dab Limanda limanda in the North Sea: gonadosomatic index, hepatosomatic index and condition factor. Journal of Fish Biology, 13: 369-378.

Jepsen, D. B., K. O. Winemiller \& D. C. Taphorn. 1997. Temporal patterns of resource partitioning among Cichla species in a Venezuelan blackwater river. Journal of Fish Biology, 51, 1085-1108.

Le Cren, E. D. 1951. The length-weight relationship and seasonal cycle in gonad weight and condition in the perch (Perca fluviatilis). Journal of Animal Ecology, 20: 201-219.

Lowe-Mcconnell, R. L. 1991. Fish communities in tropical freshwaters. London, Longman, 337p.

Maceina, M. J. \& M. C. Stimpert. 1998. Relations between reservoir hydrology and crappie recruitment in Alabama. North America Journal of Fisheries Management, 18: 104113.

Mazzoni, R. \& R. Iglesias-Rios. 2002. Environmentally related life history variations in Geophagus brasiliensis. Journal of Fish Biology, 61: 1606-1618.

Mckinney, T., R. S. Rogers \& W. R. Persons. 1999. Effects of flow reductions on aquatic biota of the Colorado river below glen canyon dam, Arizona. North America Journal of Fisheries Management, 19: 984-991.

Mota, A., E. M. Campos \& J. D. Rodrigues. 1983. Seletividade em redes de emalhar utilizadas na pesca de acará Geophagus brasiliensis Quoy \& Gaimard, 1824 (Osteichthyes, Cichlidae) e época de sua reprodução na represa de Ponte Nova, rio Tietê, Estado de São Paulo, Brasil. Boletim do Instituto de Pesca, 10: 119-127.

Nikolsky, G. V. 1969. Theory of fish population dynamics. Edimburg, Oliver \& Boyd, 323p.

Petito, J. 2002. Aspectos da história de vida de Geophagus surinamensis do alto rio Tocantins / GO. Unpublished Ms.C. Dissertation, Universidade do Estado do Rio de Janeiro, Rio de Janeiro. 79p.

Rodríguez, M. P \& T. Matsumura-Tundisi. 2001. Variation of density, species composition and dominance of rotifers at a shallow tropical reservoir (Broa reservoir, SP, Brazil) in a short scale time. Brazilian Journal of Biology, 60 (1): 01-09.

Sammons, S. M., L. G. Dorsey, P. W. Bettoli, \& F. C. Fiss. 1999. Effects of reservoir hydrology on reproduction by largemouth bass and spotted bass in Normandy reservoir, Tennessee. North American Journal of Fisheries Management, 19: 78-88. 
Santos, E. P. 1978. Dinâmica de populações aplicada à pesca e piscicultura. São Paulo, HUCITEC EDUSP, 129p.

Santos, L. N. 2002. Padrões de utilização de estruturas artificiais pela ictiofauna do reservatório de Lajes. Unpublished Ms.C. Dissertation, Universidade Federal Federal Rural do Rio de Janeiro, Rio de Janeiro. 81p.

Savino, J. F. \& R. A. Stein. 1982. Predator-prey interaction between Largemouth bass and bluegills as influenced by simulated, submersed vegetation. Transactions of the American Fisheries Society, 11: 255-266.

Spranza, J. J. S. \& E. H. Stanley. 2000. Condition, growth, and reproductive styles of fishes exposed to different environment regimes in prairie drainage. Environmental Biology of Fishes, 59: 99-109.

Thornton, K. W., B. L. Kimmel \& F. E. Payne. 1990. Reservoir limnology: ecological perspectives. New York, A Wiley Interscience Publication, 246p.
Vazzoler, A. E .A. M. \& G. Vazzoler. 1965. Relation between condition factor and sexual development in Sardinella aurita (Cuv \& Val, 1847). Anais da Academia Brasileira de Ciências, 37: 353-359.

Vila-Gispert, A. \& R. Moreno-Amich. 2001. Mass-length relationship of Mediterranean barbel as an indicator of environmental status in southwest European stream ecosystems. Journal of Fish Biology, 59: 824-832.

Williams, J. D., K. O. Winemiller, D. C. Taphorn \& L. Balbas. 1998. Ecology and status of piscivores in Guri, an oligotrophic tropical reservoir. North American Journal of Fisheries Management, 18: 274-285.

Zar, J. H. 1974. Biostatistical analysis. New Jersey, PrenticeHall, Englewood Cliffs, 620p.

Received January 2004

Accepted July 2004 